Apidologie, 1983, 14 (2), 93-103

\title{
INSECTS PRODUCING HONEYDEW EXPLOITED BY BEES IN GREECE
}

\author{
LOUKAS A. SANTAS \\ Department of Agricultural Zoology and Entomology \\ University of Agricultural Sciences of Athens \\ Athens $30 I$ - Greece
}

\begin{abstract}
SUMMARY
More than $65 \%$ of the honey in Greece derives from honeydew of insects. In a research work, started in 1977 and continued until now, 32 species of insects have been identified which produce honeydew exploited by bees.

All these insects belong to the order Hemiptera : Homoptera and to the superfamilies Aphidoidea, Coccoidea, Psylloidea and Aleyroidea. Among these 32 species, the most important from the point of the honey production, are : The coccids Marchalina hellenica (Gen.) and Physokermes hemicryphus Dalm. and the aphids Cinara confinis (Koch.) Cinara pectinatae Nördl. and Mindarus abietinus Koch.
\end{abstract}

\section{INTRODUCTION}

Honeys are derived from flower nectar, from plants which have nectaries elsewhere (extrafloral nectaries) and from the honeydew.

«The utilisation of honeydew by bees has long been recognized and honeys derived from it have considerable economic value in some parts of the world " (AUCLAiR 1963).

From statistical data of honey market of the years 1975-1976 it is obvious that more than $65 \%$ of honey production in Greece is based on honeydew. This honeydew honey according to the same statistical data, is derived from Pinus spp. (60\%) and Abies spp. (5\%) (Selianakis 1978).

The honeydew honey has a low percentage of invert sugar (glucose and fructose) high percentage of saccharose and other polysaccharides high $p \mathrm{H}(4,8-5,1)$ and it shows no crystallization during the storage. 
The main difference, between Pinus and Abies derived honey is based on the colour and flavour. Thus the Abies-honey is clear, and viscous and with good flavour while the Pine-honey is muddy and with inferior flavour (CoDOUNIS 1962).

There is also a honeydew which seems to be excreted straight from plants and appears in very small quantities usually early in spring and some times late in autumn. At these times there is frequently lack of nectar and bees exploit this honeydew, but as this is excreted in low quantities and only for a short duration its contribution to honey production is negligible.

NiCOLOPOULOS (1959) refers to about twenty plant species which seem to excrete directly honeydew. Recently three plants have been observed to give such honeydew which is exploited by bees, that is : Abies spp. which give honeydew during the spring, Ceratonia siliqua L. and Quercus sessiliflora $\mathrm{Sm}$. in autum. The honey derived from the honeydew of the two last plants is not good in quality and as reserves for the overwintering of the colonies, they create very serious problems to the beecolonies. This has been observed to the areas of Crete and Phokis and we have not concluded yet the explanation of this phenomenon. The whole subject is under investigation.

All honeydew producing insects belong to the order Hemiptera : Homoptera (Rhynchota). This group includes a large number of Coccoidea, all Aleyroidea and Psylloidea and most of the Aphidoidea and Cicadoidea (Maurizio, 1976).

Greek beekeepers often make use of abundant honeydew by bringing their hives at the proper season into host-plants which are infested by these honeydew producing insects.

Very little was known concerning these insects of Greece prior to study by Nicolopoulos (1965), SANTAS (1979 and 1981). In recent years a great deal of research has been done in Greece on the insects and some of the data which have accumulated are reported here.

\section{METHODS}

During the years 1977-1981 a country-wide survey was carried out in Greece (Fig. 1). The honeydew producing insects on which the bees were observed to forage, were collected and identified. Plant hosts of these insects were also collected and identified.

The survey was done in two steps : first extensive sampling of the plants to all migratory beekeeping areas in Greece was made to obtain information on the honeydew producing insects on which bees may forage, and second, detailed observations were carried out on the plants infested with honeydew producing insects to see bees to forage on honeydew.

The survey carried out in the main beekeeping areas and some times after information and suggestions of skilful beekeepers on biotopes which are used in the migratory and usual beekeeping areas.

These surveyed areas are :

1) North part of the Euboea island, Thassos island, Chalkidiki district and South East of Crete the main Pinus-honey producing areas, in August, September, October and March. 


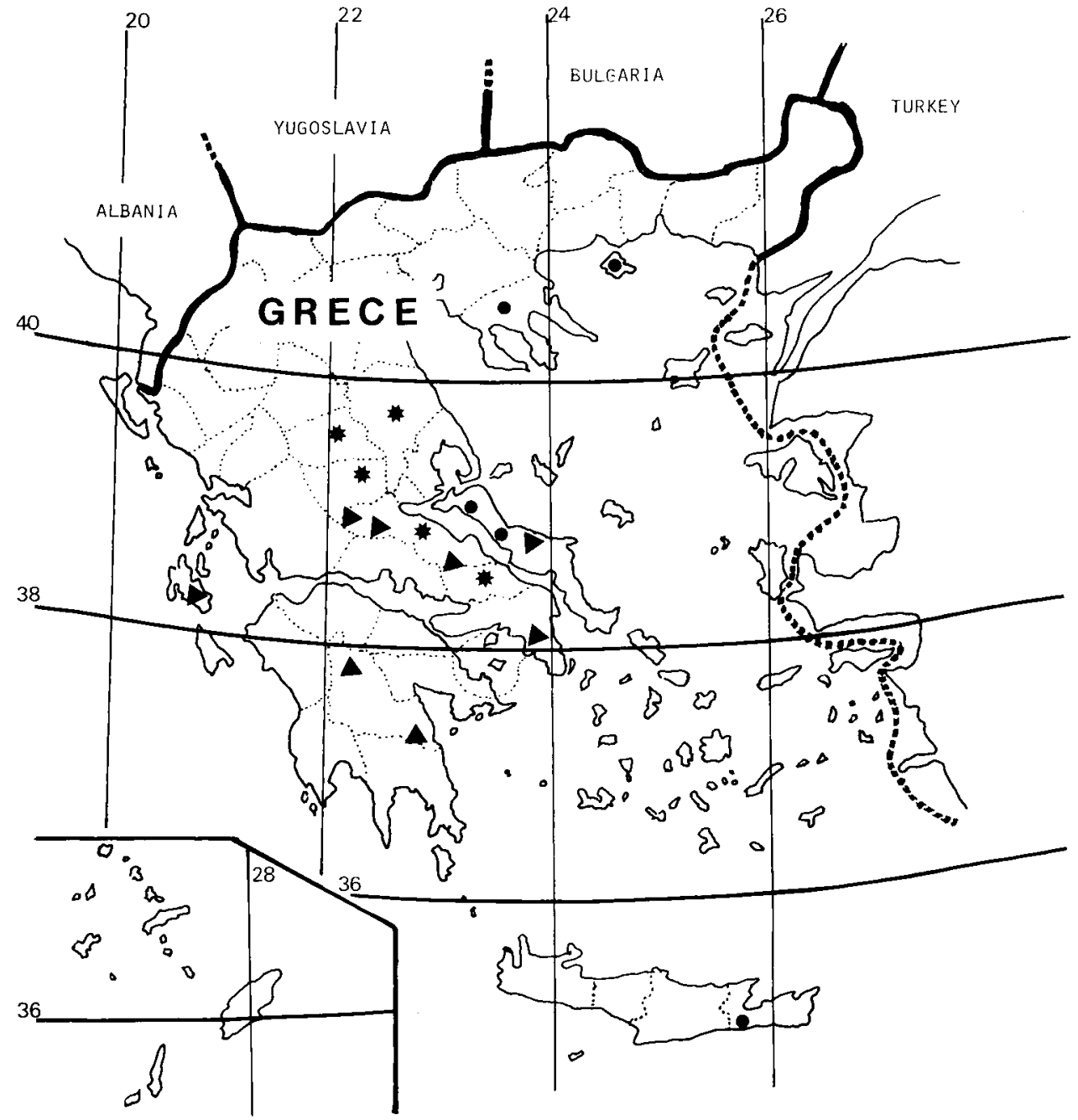

FIG. 1. - Areas on which surveys have been made.

Pinus spp.

$\Delta$ Abies spp.

$\star$ Valleys

2) The mountain of Parnis, Parnassos, Oiti, Tymphrystos Mainalon, Enos, Parnon and Ide, the main Abies-honey producing areas, in May and June.

3) The valleys of Phthiotis, Thessaly and Kopais the main glover and cotton producing areas.

The observations took place when the hives were in those places by the author and another skilful beekeeper.

The collected insects were transferred to the laboratory and some of them were identified by the author and other were sent to other specialists for identification. A quite large number of samples were sent to us by skilful beekeepers who had observed bees to forage on the honeydew. 
In addition, attempts were been made to find out the contribution of each of the honeydew producing insects, in the honey production of Greece.

Thus a number of insects were found to produce honeydew exploited by bees. From these species many are probably not of great importance because the mere fact that some bees are found foraging on honeydew does not prove that they contribute significantly to the honey production.

\section{RESULTS AND DISCUSSION}

Thirty two species of insects producing honeydew were found to be exploited by bees in our country (Tabl. 1).

TABL. 1. - Honeydew producing insects, useful to apiculture in Greece.

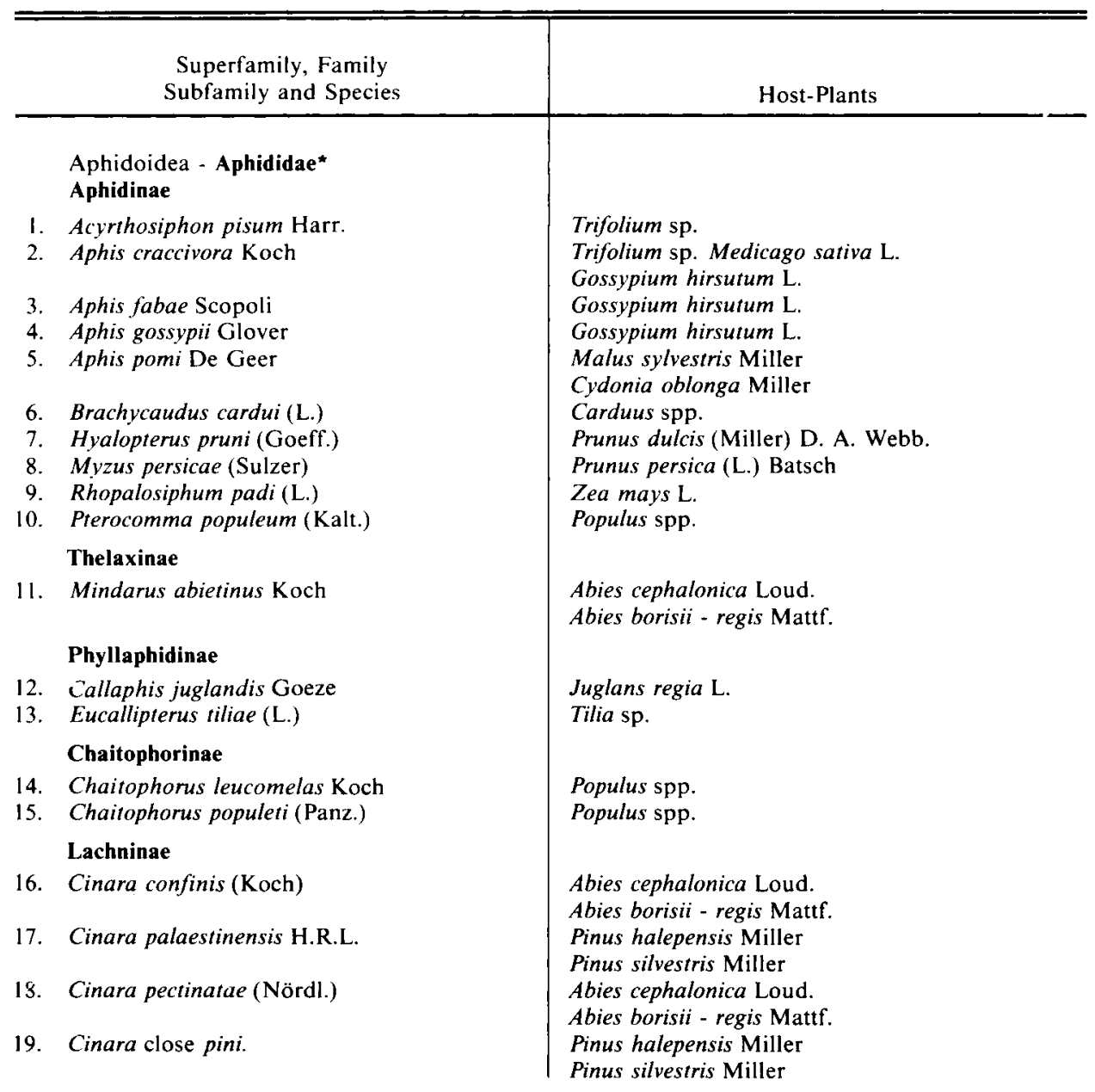




\section{Pemphiginae}

20. Prociphilus oleae (Leach et Risso)

21. Prociphilus bumeliae (Schrk.)

Coccoidea-Coccidae

22. Physokermes hemicryphus (Dalm.)

23. Eulecanium sericeum (Lind.)

24. Kermes quercus (L.)

25. Parthenolecanium corni (Bch.)

26. Sphaerolecanium prunastri (Fonsc.)

\section{Margarodidae}

27. Marchalina hellenica (Gennadius)

Psylloidea - Psyllidae

28. Euphyllura olivina (Costa)

29. Cacopsylla sp. (crataegi Schrk.)

30. Homotoma ficus (L.)

Aleyrodoidea - Aleyrodidae

31. Siphoninus phillyreae (Haliday)

32. Bemisia tabaci Genn.
Olea europaea L.

Fraxinus sp.

Abies cephalonica Loud.

Abies borisii - regis Mattf.

Abies cephalonica Loud.

Abies borisii - regis Mattf.

Quercus spp.

Prunus persica (L.) Batsh.

Prunus armeniaca $\mathrm{L}$.

Crataegus spp.

Prunus dulcis (Miller) D. A. Webb.

Prunus avium L.

Pinus halepensis Miller

Pinus silvestris Miller

Pinus pinea $\mathrm{L}$.

Pinus brutia Ten.

Olea europaea L.

Crataegus sp.

Ficus carica $\mathrm{L}$.

Pyrus communis L.

Gossypium hirsutum L.

(*) The classification of Aphidoidea has been based in some case on the work of R. J. Blackman (1980), and in some other cases on some other works.

This number is small compared with that found in central Europe ( 58 known) (KUNKEL and KLOFT, 1977).

These species may be divided into two groups. The first group comprises all those insects which have a great contribution to honey production in Greece. These are all the species which actually are exploited in Greece by beekeepers who transfer the hives to their biotopes. These are : Marchalina hellenica, Physokermes hemicryphus, Cinara confinis, Cinara pectinatae, and Mindarus abietinus.

The second groupe consists of those species which only partially contribute to honey production or those which are not very important to the honey production, being incidental foraged for the bees. These are the rest twenty seven species of Tabl. 1.

It is quite possible that this division does not give an accurate estimate of the importance of these species with respect to the honey production since the bees are capable of changing their forage if the principal source is not available. Nevertheless the five aforementioned species must be regarded as important source of forage for bees. 
As it was estimated that the honeydew honey produced from the coniferous trees forests accounts for the $60-65 \%$ of honey production in Greece while the contribution of broad-leaved trees and other host plants has not been estimated yet.

In our country, the different species of Pinus are the main host plants fot the most important honeydew producing insects useful to honey production. The insects which produce honeydew on Pinus are : M. hellenica, C. palaestinensis and C. close pini. Taxonomically this species is not yet clear. Dr. G. Remaudiere of Inst. Pasteur, Paris, is on the way to make a detailed analysis. It will appear from our study that $M$. hellenica (Fig. 2,3) is the main source of forage for the bees since $55-60 \%$ of honey production in our country is from this scale insect (SANTAS, 1979).

This species is widely distributed in almost all pine forests all over Greece and supports the bulk of migratory beekeeping. The time of excretion of this insect is from June to following spring but the bees, depending on the area, forage on that honeydew in August, September, October and to a smaller extent in March and April (SANTAS, 1979, 1981).

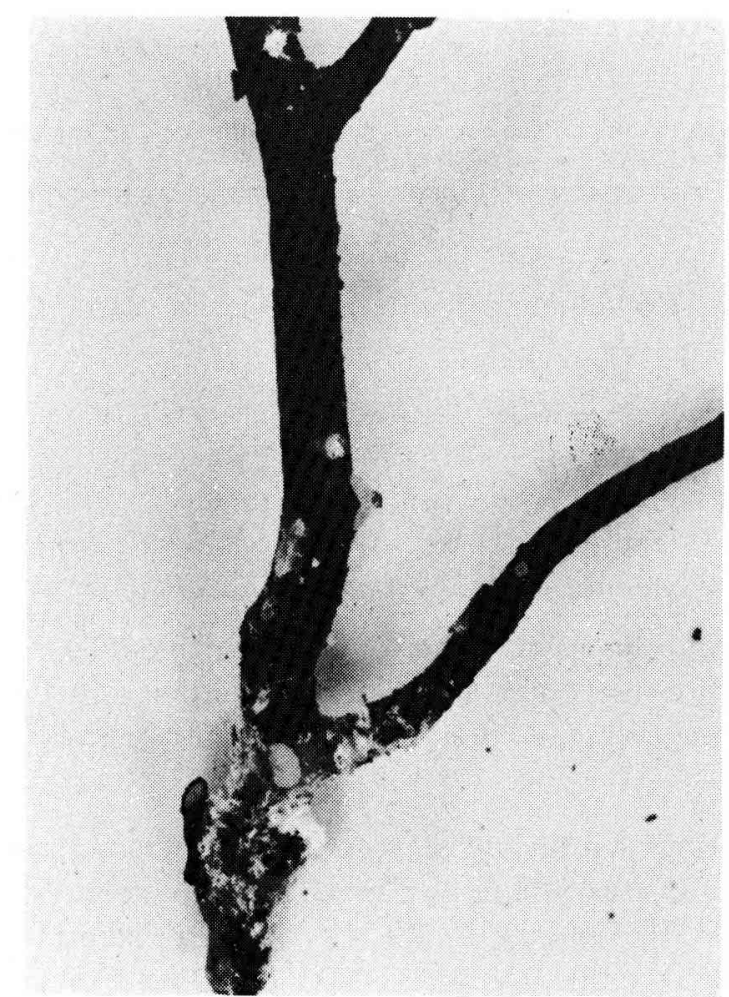

FIG. 2. - A pine-twig infested by Marchalina hellenica (Genn.). 


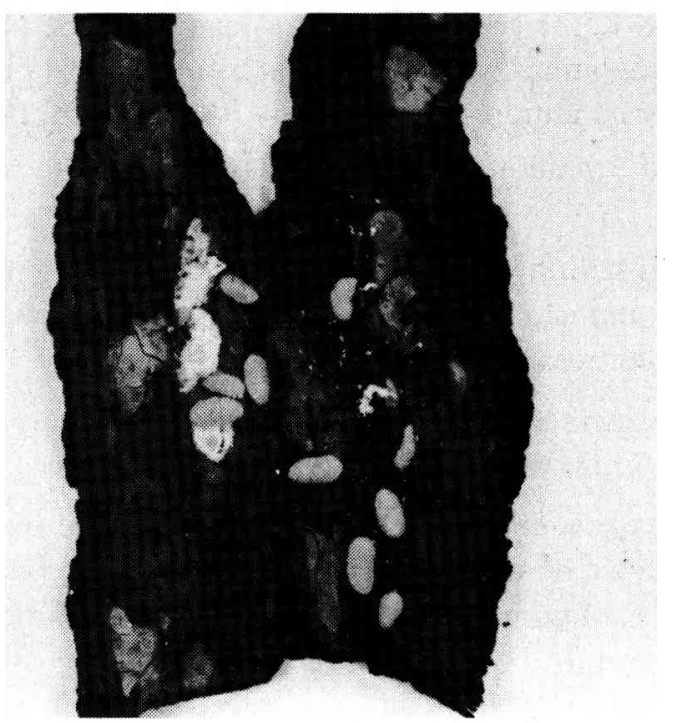

FIG. 3. - Mature females of Marchalina hellenica (Genn.) on pine-bark.

The exact contribution to honey production of $C$. palaestinensis and $C$. close pini is not known, as the infestation of Pinus by these aphids is not in large areas but in planches here and there.

Yet the infestation by these insects do not appear every year. This depends on the weather, entomophagous insects and other factors.

Second in importance as host-plants of honeydew producing insects are the different Abies species, as they contribute, 5-10\% of all the honey producted in Greece. The insects which produce honeydew on Abies trees are : The scales $P h$. hemicryphus, E. sericeum and the aphids C. confinis, C. pectinatae and M. abietinus, with Ph. hemicryphus being the most important. The infestation of Abies trees by this scale appears more or less in large Abies forests. The beekeepers bring their hives to these Abies forests as most of the foraging is done in May-June and early July (SANTAS, 1981) but the exact time depends on the altitude of the forests and on the weather.

The scale E. sericeum appeared in patches on the Abies trees in the forest, although sometimes a whole tree may be infested. Nevertheless its contribution to honey production appeared to be negligible. The time of excretion of this insect was from October to June-July, but the bees exploit it only during May to July (SANTAS, 1981).

The aphids, $C$. confinis, C. pectinatae and abietinus appeared in our Abies forests, but their contribution to honey production is unknown. In some areas and in some years the population of one species is higher than the other two for some undetermined reasons. 
It is known however that there are many factors, biotic and abiotic, which influence the population of insects, such as available host plants, parasites predators, altitude, weather conditions, etc. (URANOv, 1931 ; SMITH, 1935; PECHHACKER, 1977).

The time of excretion of these insects starts in May-June and continues until September.

In the years with high population of $C$. confinis, the honeydew is available in large quantities and can cover the leaves, twigs, trunks and even the ground under the infested Abies trees.

Since beekeepers know the irregularity in the appearance of these insects, they will survey the forage areas before transfering their hives in these areas.

Another forage area in Greece is the chestnut tree forests. The chestnut tree is a very well known honey plant and an important source of honeydew. This tree flourishes in late May and June and provides good forage for bees with nectar, pollen and honeydew. The honeydew is excreted by the Myzocallis castanicola which is appears in high population levels in the underside of leaves. The production of honeydew is very abundant from May to July and later on.

There are some other forage areas with plants which do not form forests but which are scattered or are growing in clusters.

Among them the different species of Populus are planted in clusters for timber, along the roads or for windbreaks for ornamental reasons or scattered.

The most important species found in Greece are : Populus canadensis Moench, Populus nigra L., Populus thevestina Dode and Populus alba L. Besides pollen those trees provide bees honeydew in the spring. This honeydew is excreted by the aphids Chaitophorus populeti. Chaitophorus leucomelas, and Pterocomma populeum. The forage time is late May until early June. The quantity of honeydew honey produced is sometimes high but there are no accurate data on the contribution to honey production.

In the same group is the Tilia sp. which provides a good quality honey from nectar and honeydew. The honeydew is produced by the aphid Eucallipterus tiliae (L.) which lives in the underside of the leaves. This insect produces large quantities of honeydew in May and June. The Tilia sp. are scattered in the northern parts of the country.

On Crataegus spp., which are grown almost all over Greece two species of insects produce honeydew on which the bees have been observed to forage : the coccid P. corni and the psyllid Psylla sp. On Fraxinus sp. by the aphid Prociphilus bumeliae (Schrk.) large quantities of honeydew on which the bees forage are produced.

Honeydew is also produced on Quercus spp. by the coccid Kermes quercus (L.). The infestation on Quercus spp. by this insect was found to be very low. 
Bees have also been observed to forage honeydew produced on cultivated trees, plants and weeds (Tabl. 1).

It is also worth mentioning the contribution of honeydew production from cotton, clover and maize.

The beekeepers transport their colonies to the cotton and clover plantations from July to August for the flowers. At the same time if there is a honeydew production, the bees forage on it. The honeydew in cotton plants is produced by Aphis craccivora, Aphis fabae, Aphis gossypii and Bemisia tabaci and in clover plants by Acyrthosiphon pisum and Aphis craccivora.

Generally in the case of cultivated plants, the farmers usually apply insecticides against those insects and for that reason there is no data on the accurate contribution to honey production.

\section{ACKNOWLEDGMENTS}

We wish to express our sincere thanks to Mr V. PAPAgeorgiou, président of "Melissokomiki » co-operative union of beekeepers associations and to all agriculturists and skilfull beekeepers for their help during this work.

Received for publication in August 1982.

\section{RÉSUMÉ}

LES INSECTES QUI PRODUISENT UN MIELLAT BUTINÉ PAR LES ABEILLES EN GRĖCE

Plus de $65 \%$ de la production totale de miel en Grèce provient du miellat d'insectes. Une étude, commencée en 1977 et basée d'une part sur l'échantillonnage des insectes qui produisent un miellat exploité par les abeilles et d'autre part sur l'échantillonnage de leurs plantes-hôtes, a permis d'identifier 32 espèces d'insectes producteurs de miellat. Les prélèvements ont été effectués dans presque toutes les régions de Grèce. Tous ces insectes appartiennent à l'ordre des Hémiptères-Homoptères et aux superfamilles Aphidoidea, Coccoidea, Psyloidea et Aleyroidea.

Parmi les 32 espèces rencontrées les plus importantes du point de vue de la production de miel sont les coccides Marchalina hellenica (Genn.) et Physokermes hemicryphus (Dalm.) et les aphides Cinara confinis (Koch.), Cinara pectinatae (Nördl) et Mindarus abietinus Koch.

Il ressort de notre étude que $M$. hellenica est l'insecte producteur de miellat le plus important; c'est lui qui est à l'origine du miel de pin de Grèce. D'après les statistiques ce miel représente $55-60 \%$ de la production globale du pays. M. hellenica se rencontre sur diverses espèces de Pinus et dans la plupart des forêts de pin de Grèce. Les sécrétions de miellat commencent en juin et se poursuivent jusqu'au printemps suivant, mais les abeilles le butinent essentiellement en août, septembre et octobre et, à un moindre degré, en mars et avril. 
Les insectes qui vivent sur les diverses espèces d'Abies viennent en deuxième position avec une contribution de 5 à $10 \%$ à la production annuelle de miel. Dans les forêts de sapins nous avons trouvé 5 espèces qui sécrètent du miellat, Physokermes hemicryphus étant la plus importante.

Au printemps les agriculteurs transhument dans les forêts de sapins mais les abeilles n'exploitent le miellat qu'en mai, juin et début juillet.

\section{ZUSAMMENFASSUNG}

\section{DIE HONIGTAUPRODUZIERENDEN INSEKTEN GRIECHENLANDS UND DIE AUSNUTZUNG DER WALDTRACHT DURCH BIENEN}

Mehr als $65 \%$ der gesamten Honigproduktion in Griechenland basiert auf Honigtau von Insekten. 1977 wurde eine Forschungsarbeit begonnen, die zum einen aus der Sammlung von honigtauproduzierenden Insekten, die von den Bienen besucht werden, bestand, zum anderen aus der Sammlung von Wirtspflanzen. 32 Arten von honigtauerzeugenden Insekten wurden identifiziert. Die Proben stammten aus fast ganz Griechenland (Fig. 1). Alle gefundenen Insekten gehören zu der Ordnung Hemiptera, Unterordnung Homoptera und zu den Familien Aphidoidea, Coccoidea, Psylloidea und Aleyrodoidea.

Unter den 32 gefundenen Arten waren die im Hinblick auf die Honigproduktion bedeutendsten : Marchalina hellenica (Genn.), die Schildlaus Physokermes hemicryphus (Dalm.), die Rindenläuse Cinara confinis (Koch.) und Cinara pectinatae (Nördl.) und Mindarus abietinus (Koch.).

Aus unseren Studien geht hervor, daß Marchalina hellenica das wichtigste honigtauerzeugende Insekt ist, von dem der Pinien-Honig in Griechenland stammt. Dieser Honig macht nach statistischen Angaben $55-60 \%$ der gesamten Honigproduktion dieses Landes aus. Die Spezies $M$. hellenica kommt auf verschiedenen Pinus-Arten vor und wird in fast allen Pinienwäldern dieses Landes gefunden. Die Honigtausekretion beginnt im Juni und dauert bis zum nächsten Frühjahr, aber die Bienen sammeln davon nur im August, September, Oktober und in geringerem Maße im März und April.

Die zweitwichtigsten Insekten sind solche, die auf den verschiedenen Abies-Arten sitzen, da 5-10\% der jährlichen Honigproduktion des Landes vom Honigtau dieser Insekten stammt. In den Tannenwäldern fanden wir fünf Arten, die Honigtau produzieren. Unter ihnen ist Physokermes hemicryphus die wichtigste.

Die Imker transportieren ihre Bienenvölker im Frühjahr in die Tannenwälder, aber die Bienen sammeln den Honigtau nur im Mai, Juni und frühen Juli.

\section{REFERENCES}

Auclair J. L., 1963. - Aphid feeding and nutrition. Annual Rev. of Entom., 8, 439-490.

Blackman R. J., 1980. - Chromosome numbers in the Aphididae and their taxonomic significance. Syst. Entomol., 5, 7-25.

Codounis M., 1962. - La crystallisation du miel. Thèse Doct. Univ. d'Agric. d'Athènes, pp. 25-31 (in Greek).

Kunkel H. und Kloft W., 1977. - Fortschritte auf dem Gebiet der Honigtau - Forschung. Apidologie. 8 (4), 369-391.

MAurizio A., 1976. - How Bees make honey. In CRANe, E., Honey a comprehensive survey, p. 94, London. 
Nikolopoulos Chr., 1965. - Morphology and biology of the species Marchalina hellenica (Gennadius) (Hemiptera : Margarodidae : Coelestomidiinae), $31 \mathrm{pp}$. Athens (in Greek).

Nikolopoulos Chr., 1959. - Apicultural flora of Attica, pp. 21-23. Athens (in Greek).

Pechracker H., 1977. - Über die Auswirkung von Umwelteinflüssen auf die Populations-Entwicklung der Physokermes-Arten. Apidologie, 8 (4), 45i-457.

Santas L. A., 1979. - Marchalina hellenica (Gen.) an important insect for apiculture of Greece, Apimondia XXVII Inter. Congr. Athens, pp. 419-422 Apimondia Publishing House, Bucharest, Romania.

SANTAS L. A., 1981. - Insects useful to apiculture in Greece. XXIIIth Intern. Congr. of Apiculture held in Acapulco-Mexico on 23-29 Octob. 1981 (in press).

Selianakis G. V., 1978. - Greek apiculture in the regime of Europeans Community, p. 13. Athens (in Greek).

SмIтн H. S., 1935. - The role of biotic factors in the determination of population densities. J. econ. Ent., 28, 873-898.

Uranov B. P., 1931. - Insects and climate. Trans. Ent. Soc. London. 79, 1-247. 